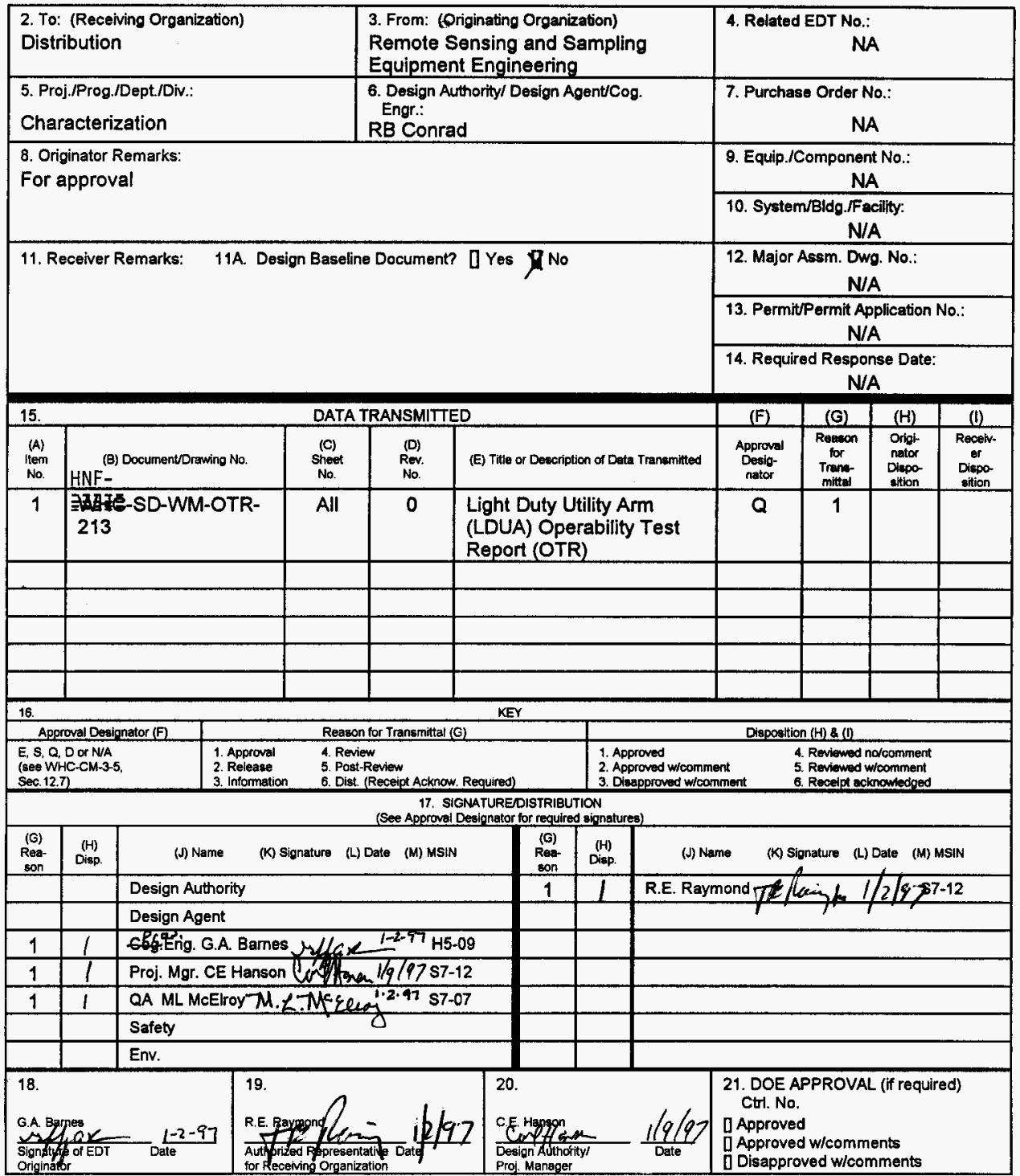

B0-2400-172-2 (05N6) 0EFag7 


\section{LIGHT DUTY UTILITY ARM (LDUA) OPERABILITY TEST REPORT (OTR)}

\section{RB Conrad}

SGN Eurisys Services Corporation (SESC), Richland, WA 99352

U.S. Department of Energy Contract DE-AC06-87Rt-1093096RL13200
EDT/ECN: 619106
UC: 2070
Org Code: $08 E 00$
Charge Code: E58329
B\&R Code: EW3120074
Total Pages: 45

Key Words: LDUA, OTP, OTR, subsystems, test, Operations

Abstract: The objective of the test was to demonstrate that the LDUA and subsystems that are applicable to the T-106 deployment could be safely deployed in the field and operated as designed per the operating procedures.

TRADEMARK DISCLAIMER. Reference herein to any specific commercial product, process, or service by trade name, trademark, manufacturer, or otherwise, does not necessarily constitute or imply its endorsement, recommendation, or favoring by the United States Government or any agency thereof or its contractors or subcontractors.

Printed in the United States of America. To obtain copies of this document, contact: HHC/BCS Document Control Services, P.0. Box 1970, Mailstop H6-08, Richland WA 99352, Phone (509) 372-2420; Fax (509) 376-4989.
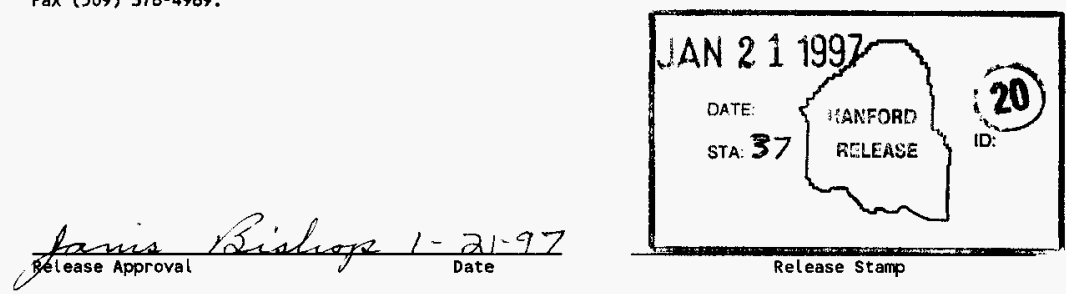

\section{Approved for Public Release}


HNF-SD-WM-OTR-213, REV 0

\title{
LIGHT DUTY UTILITY ARM (LDUA) OPERABILITY TEST REPORT
}

\author{
R. B. CONRAD \\ OCTOBER 1996
}


TABLE OF CONTENTS

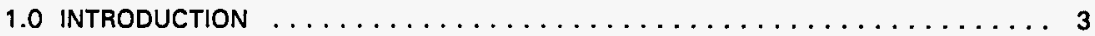

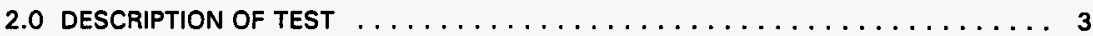

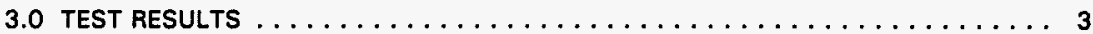

3.1 SUBSYSTEM SETUPIENERGIZATION (OTP STEP 5.1 ) $\ldots \ldots \ldots \ldots \ldots 3$

3.2 ALIGNMENT (OTP STEP 5.3$) \ldots \ldots \ldots \ldots \ldots \ldots \ldots \ldots \ldots$

3.3 IN-TANK OPERATIONS (OTP STEP 5.4 THROUGH 5.19 ) . . . . . . . 7

3.4 TAKE DOWN (TO-080-703) $\ldots \ldots \ldots \ldots \ldots \ldots \ldots \ldots \ldots \ldots . . \ldots$

3.5 OFF-NORMAL $\ldots \ldots \ldots \ldots \ldots \ldots \ldots \ldots \ldots \ldots \ldots \ldots$

4.0 CONCLUSIONS AND RECOMMENDATIONS $\ldots \ldots \ldots \ldots \ldots \ldots \ldots \ldots \ldots$

5.0 DISPOSITION OF TEST ITEMS $\ldots \ldots \ldots \ldots \ldots \ldots \ldots \ldots \ldots \ldots$

6.0 REFEREnCES $\ldots \ldots \ldots \ldots \ldots \ldots \ldots \ldots \ldots \ldots \ldots \ldots \ldots \ldots \ldots \ldots \ldots$

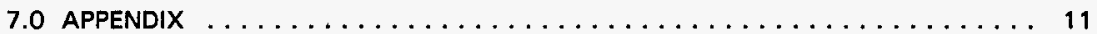




\section{LIST OF ACRONYMS}

$\begin{array}{ll}\text { ATIE } & \text { At-Tank Instrument Enclosure } \\ \text { CTF } & \text { Cold Test Facility } \\ \text { DOE } & \text { U.S. Department of Energy } \\ \text { DOE-RL } & \text { U.S. Department of Energy-Richland Operations } \\ \text { DWSS Decon Water Supply System } \\ \text { EE } & \text { End effector } \\ \text { HPT } & \text { Health Physics Technician } \\ \text { MEEES } & \text { Manual end effector exchange system } \\ \text { F\&R } & \text { Functions and Requirements for the Light Duty Utility Arm Integrated System } \\ & \text { (WHC-SD-TD-FRD-O03, (Kiebel, 1996a)) } \\ \text { HRSVS } & \text { High Resolution Stereo Video System } \\ \text { LDUA } & \text { Light-Duty Utility Arm } \\ \text { LMHC Lockheed Martin Hanford Corporation } \\ \text { MDS } & \text { Mobile Deployment System } \\ \text { NEC } & \text { National Electric Code } \\ \text { NHC } & \text { Numatec Hanford Corporation } \\ \text { OAS } & \text { Optical Alignment Scope } \\ \text { ORR } & \text { Operational Readiness Review } \\ \text { OVS } & \text { Overview Video System } \\ \text { PASS } & \text { Purge Air Supply System } \\ \text { PDS } & \text { Power Distribution Skid } \\ \text { PNNL } & \text { Pacific Northwest National Laboratory } \\ \text { RBA } & \text { Radiological Buffer Area } \\ \text { SDAS } & \text { Supervisory Data Aquisition System } \\ \text { SESC } & \text { SGN Eurisys Services Corporation } \\ \text { SMP } & \text { Surface Moisture Probe } \\ \text { SST } & \text { single-shell tank } \\ \text { SWP } & \text { Special Work Permit (protective clothing) } \\ \text { TMS } & \text { Topographical Mapping System } \\ \text { TRIC } & \text { Tank Riser Interface Confinement System } \\ \text { VPM } & \text { Vertical Positioning Mast } \\ \text { WHC } & \text { Westinghouse Hanford Company } \\ & \end{array}$




\section{LIGHT DUTY UTILITY ARM (LDUA)}

OPERABILITY TEST REPORT

\subsection{INTRODUCTION}

The goal of the operability test procedure (OTP) was to set up and assemble the Light Duty Utility Arm (LDUA) system at T-106, operate the LDUA inside of T-106 and perform tasks with each available end effector within that tank. The test was authorized by the test plan (Conrad, 1996) and was performed between September 16, and September 30,1996 at T-106. The test was successful.

Organizations involved in the testing included; Characterization Equipment Engineering, TWRS Characterization Project Operations, Remote System and Sensor Applications, and CPO crafts. Funding was provided by TWRS (EM30).

\subsection{DESCRIPTION OF TEST}

The objective of the test was to demonstrate that the LDUA and subsystems that are applicable to the T-106 deployment could be safely deployed in the field and operated as designed per the operating procedures.

See the attached OTP for a description of the test. At the time the OTP was written it was not certain whether the Optical Alignment Scope and gamma detector would be used and was so noted. As anticipated, they were not used as part of this test, as noted in exceptions 1 and 2 of Appendix B, Exception List in the attached OTP.

The equipment was setup at $T$ farm on September 17, 1996, cabling connected and powered up on September 18, Tank Riser Interface Confinement System (TRIC) was installed on September 19, and shakedown testing was performed on September 20, 1996. The U.S. Department of Energy (DOE) Operational Readiness Review (ORR) approval was obtained on September 26, 1996. Alignment of the vertical positioning mast (VPM) was performed on swing shift September 26, 1996. The High Resolution Stereo Video System (HRSVS) was deployed on day shift, September 27, and the gripper end effector was dep?oyed on September 30, 1996. Takedown began on swing shift of the same day.

\subsection{TEST RESULTS}

The results are organized below according to the chronological sequence of the procedures. Within each procedure they are further separated into subcategories of procedure, equipment and personne1. Data required by the 0TP steps are referenced accordingly.

\subsection{SUBSYSTEM SETUP/ENERGIZATION (OTP STEP 5.1)}

The actual duration required to set up was 2 shifts. The TRIC was not 
set up till the third day due to issues with the ORR. It is not an unreasonable goal to be able to perform setup in one shift if certain improvements are made.

Once the Vitis camera was installed the world model could be checked for accuracy (0TP step 5.2). Exception \#3 describes the discrepancies. Since T106 had so much open space, the discrepancies were not a problem. However, in a tank such as $A X-104$ where there are so many air lift circulators, the world model will be relied upon more.

\subsubsection{Procedure (T0-080-700)}

A step should be added to ensure the marmon clamp on the TRIC assembly is aligned properly.

The PIC has requested that the procedure

- be revised to allow flexibility to use spare fiberoptic wires if necessary during the setup.

- allow flexibility to use various power sources such as portable substation, generator, etc.

\subsubsection{Equipment}

More radios need to be purchased including a base set and 4 headsets. A minimum of eight are needed with spares available. Currently there are only four (four additional were borrowed from 200 East Operations).

The electricians did not like the cable reels provided for power and fiberoptic. In fact they ended up abandoning the power cable reels altogether and simply coiled the 50 and 200 foot lengths of cable on pallets using a crane crew to stage them. An evaluation should be made to identify what improvements could be made. Cable layout turned out to be a time consuming part of setup.

The OVS camera that was developed for the LDUA operation was not used. In-tank camera video imaging was performed using a VITIS II camera due to the need for significantly better control and optical resolution. The shoulder mounted camera inside the VPM was not used.

\subsubsection{Personnel}

Adequate personnel were made available for this deployment.

\subsection{ALIGNMENT (OTP STEP 5.3)}

Alignment of the VPM housing took less than one shift. The 0ptical Alignment Scope (OAS) was not used because of problems identified during the qualification test. This was noted as Exception \#2. A visual alignment technique was developed and used for this deployment. With more repetition, the time to perform this task could be reduced to one or two hours. It was performed at night to reduce the glare from the sun in the TRIC. Alignment was successful on the first attempt, there was no apparent contact with riser 
during tank entry.

\subsubsection{Procedure (T0-080-701)}

The EM-50 design authority recommends that the parameters, "distance between top of riser and bottom of mast housing" and "Riser length" on the power screen of the LDUA Console should be calculated using the method used in step 12.2.14 of the LDUA Equipment Qual ification Test (Kiebel, 1996). This method uses the distance between the bottom of the VPM housing and the top of the TRIC. Instead a straight measurement of the riser to VPM housing distance was used. It is not as accurate and doesn't allow for end effector length adjustment.

Rough alignment of Mobile Deployment System (MDS) to the riser was okay, but was several inches to one side (MDS $Y$ axis). A method or tool to optimize rough alignment of the truck to the riser would be desirable. Although not a problem in this deployment, a bad rough alignment of the MDS to the riser would require significant time to re-adjust the MDS because it would not be identified till the outriggers were deployed, utilities connected and the VPM housing raised, etc.

PNNL, funded through EM-50, is working on optimizing and finalizing visual alignment guides. This procedure should be revised accordingly when they have completed this task.

\subsubsection{Equipment}

Slow Movement of Pitch Axis

The pitch axis continued to exhibit a condition where it required the operator to slowly raise and lower the VPM housing. The warning message indicates that the hydraulic fluid level is low. Operators must wait till the hydraulic fluid level raises before the housing can be moved again. PNNL is aware of this problem and is evaluating a corrective action.

Pitch Axis Slippage

While the initial alignment was successful, the VPM experienced a slow gradual slip from negative to positive (see log, Appendix C of attached OTP). A positive pitch movement is one in which the top of the housing moves to the rear of the truck. A negative pitch movement is one in which the top of the VPM housing moves toward the front of the truck. On Friday September 27 , 1996, this slight positive movement resulted in the arm contacting the riser upon removal which shifted one boot clamp and caused slight tearing of the boot. The tears were between two joints so purge pressure was not significantly affected. Contact was on the positive $x$ side of the arm (towards front of truck). This slippage occurred after the arm was deployed into the tank because at tank entry, the inclinometer readings matched that of the initial alignment (pitch axis $=-.16^{\circ}$ ). Observations noted during initial tank entry was that there was more room on the positive $x$ side (front of truck) than on the negative $x$ side. The pitch axis at time of removal from tank on Friday was $+.19^{\circ}$.

On Monday, VPM housing position was returned to that of the initial 
HNF-SD-WM-OTR-213, REV 0

alignment and locked in place. The inclinometers were monitored to determine rate of slip. A slow steady rate of slippage was observed. Operation was halted and a meeting took place which included Lockheed Martin Hanford Corp (LMHC); CPO Operations Management and Numatec Hanford Corp (NHC); Characterization Equipment Engineering (CEE) Management to discuss path forward. Since the slippage was slow and predictable, and a safe recovery was possible if a slip limit was reached, it was decided to continue with deployment of the GEE. The direction of CEE Management was to abort the gripper deployment if the pitch reached a positive $.1^{\circ}$. Inclinometer readings were noted every 5 minutes (see test log, Appendix $C$ of attached OTP). The pitch axis never went more than a positive $.02^{\circ}$ while the gripper was in the tank and tank exit was accomplished without any further damage to the boot.

This behavior had not been observed before. Possible contributing factors include:

1) Several days prior to deployment into tank farm, painters were directed to paint surfaces that were experiencing rust, unfortunately they painted the pitch axis brake surfaces.

2) The manufacturer predicted some deflection of the VPM housing due to thermal expansion caused by the sun.

A painted brake surface will be more slippery and may require more torque of the brake bolts to keep the housing stationary. The paint must be removed from the brake surfaces.

The MDS was positioned with the front of the truck facing the west so the afternoon sun would heat the front side of the VPM housing. This is consistent with the VPM tubes experiencing a pitch movement in the positive direction.

The VPM did not undergo movement on the Roll axis, and this may provide some further information to be used in comparison. The Pitch axis is controlled hydraulicly, using brakes to maintain desired position, and the Roll axis is controlled manually using, essentially, a large mechanical jacking screw with a brake to maintain desired position.

Procedurally, adjustment of the Pitch, Roll, $X$ and $Y$ parameters is not allowed with the VPM deployed in the tank. Because of the positive manuai adjustment capability of the Roll axis it would be possible, if necessary, during an off-normal situation, to change the roll axis angle with the VPM deployed inside the tank and to do so safely without damaging the arm. Due to the Pitch, $X$ and $Y$ axes hydraulic design parameters could not be safely changed in such an off-normal situation. Operations expressed a very strong interest toward incorporating some form of manual adjustment into the operation of the Pitch, $X$ and $Y$ axes to allow for this type of contingency. off-normal situations that could result in misalignment include brake slippage as postulated above, shifting of the MDS due to ground settling or other external phenomena.

PNNL has been asked to evaluate the problem and will provide conclusions and recommendations to SGN Eurisys Services Corporation (SESC). 


\section{Other Observations}

PNNL will continue to improve on the visual alignment guides. Alignment is one of the most critical parts of the operation.

Move 00VS controls closer to SDAS operator to facilitate adjustment.

The riser isolation valve handle is cumbersome to operate when its position under the platform. Improvements may include a remote operating device longer handle or an angled handle.

\subsubsection{Personnel}

An issue from the $0 R R$ resulted in operations mgmt to require the field operations personnel to wear hard hats when up on the platform operating the manual end effector exchange system (MEEES) and changing end effectors.

Operations personnel had difficulty wearing both the hard hat and radio head sets. Operations will consider ways to eliminate the need for hard hats by removing potential sharp points, edges, etc., and/or provide padding.

\subsection{IN-TANK OPERATIONS (OTP STEP 5.4 THROUGH 5.19)}

The gamma detector was not used in this deployment. The intent was to deploy a gamma detector in an adjacent riser, grasp it with the GEE and obtain readings following the same path taken by the HRSVS. Due to schedule and budget conflicts the detector could not be made available for this deployment. The OTP allowed for this possibility. Therefore, OTP steps 5.10 and 5.12 through 5.16 could not be performed (see exception \#4, Appendix B of attached OTP).

\subsubsection{Procedure}

A step should be added to the tank exit/decon section to manually isolate the GEE at the at-tank instrument enclosure (ATIE) during decon to enhance safety.

\subsubsection{Equipment}

The HRSVS provided very clear views (OTP step 5.6). The stereo cameras enabled the viewer to see features of the tank dome, wall and waste that would have been difficult to see with a mono camera. Interesting features included an indication of pitting in a vertical weld near the bottom of the wall. The pit seemed to be as deep as the weld was wide. A possible improvement would be to enable an operator to determine width or depth of objects or follow the same locations with the gripper, holding a depth gauge or some other measuring device.

The GEE performed well (OTP step 5.17) however the indication for actual gripper force does not seem to be accurate. This should be fixed or removed from the screen. The stereo vision was crucial in helping determine when the discarded manual tape was within grasp of the gripper jaws. The SDAS operator was able to grasp the tape with the first try. OTP step 5.17 took only one hour from opening the riser isolation valve, performing tank entry, object manipulation, tank exit and decon. Water decon was not necessary during this 
entire deployment. Manual decon with towels was all that was required. Following decontamination efforts, both end effectors and the TRIC internals were completely free of removable contamination. The TRIC was cleared to open the door with blues (SWPS not required) to remove both the HRSVS and GEE.

The radiation detectors on the decon module never indicated any readings above background. HPTs instruments indicated a field of 250 counts per minute.

The LDUA console could be improved by enabling the operator to monitor purge pressure while having the VPM screen displayed. PNNL has been requested to evaluate if this can be accomplished.

SDAS continued to require rebooting from time to time. PNNL is working to improve its performance. The guest SDAS station seemed to cause problems with the main SDAS console but was not significant. Had problems obtaining stereo vision with the HRSVS at one point but rebooting SDAS re-enabled the stereo.

SDAS seemed to be a bottle-neck for performing in-tank tasks mostly due to the management of the video. Significant time was required of the SDAS operator to ensure the two VCRS had tapes in them, the tapes were marked, switching views from various cameras to be recorded, changing titles to correspond to the subject, etc. PNNL is considering ways to address this as they work to improve SDAS. Options include making it easier to switch screens, customize screens (favorite items), move Oovs controls closer to SDAS operator, etc.

There were problems obtaining stereo color for a short period. .Color was quickly restored and the problem was suspected to be a connector problem in the output of the side by side video switcher.

The second VCR destroyed a tape during deployment of the HRSVS and was not used again. Possible equipment improvements for tank entry and exit include;

- A microphone to enable audio indication of contact with riser.

- A small hand held camera held via TRIC gloves to allow viewing down riser as arm is lowered. This would facilitate visual indication of how good the alignment was by seeing how close the $\mathrm{arm} / \mathrm{vpm}$ tubes are to the inside of the riser. This is currently done by a hand held mirror.

\subsubsection{Personnel}

About 20 hours of video tape was recorded during this deployment. Source's included the OOVS, VITIS, and EE cameras (HRSVS and GEE). SDAS operations could be made more efficient if tapes were pre-marked, and a more definite "tank inspection plan" was made. Such a plan would have input from experts knowledgeable in concrete, corrosion, welding, waste, tank internals, etc. and may require subject experts to be on hand to guide operations on what was important and what was not. For example, views of the tank dome may have been interesting to someone with dome loading or dome pressure questions. 
The radios worked extremely well in facilitating the close coordination of the OCT and in-farm operating crews (VITIS and TRIC). The only problem was that there was not enough of them.

Crowd control in the OCT was a problem during the first day. Operations took a more aggressive posture in controlling the number of people allowed in the operating area of the OCT during the second day.

\subsection{TAKE DOWN (T0-080-703)}

No problems were reported with the procedure, equipment, or personnel.

\subsection{OFF-NORMAL}

An off-normal procedure should be prepared to address conditions where pitch axis exhibits movement while in a locked condition whether in or out of a tank and also consider the need to address all MDS axis movement. The only times we found it necessary to use the off-normal procedure, TO-080-704, was in regard to computer software problems that required us to reboot the MDS and the SDAS.

\subsection{CONCLUSIONS AND RECOMMENDATIONS}

The OTP was a success in that it demonstrated that the equipment generally operated as designed, operations personnel were properly trained, and LDUA procedures were accurate, all of which enabled the LDUA system to be operated safely in an underground waste tank.

It is recommended that problems identified in this report be fixed. The pitch axis slippage cannot be tolerated even though we were able to operate safely with this problem. It is further recommended that the potential improvements identified above be evaluated and incorporated if deemed prudent and cost effective.

\subsection{DISPOSITION OF TEST ITEMS}

The OCT, MDS, ATIE, HRSVS, GEE and PDS shall be moved to FMEF to allow problems and improvements to be made and to support testing of the second LDUA which is to be stationed at FMEF. Operations shall decide where the most desirable storage location for the rest of the equipment shall be. Options include FMEF, 2101HV, or 2101M. The OCT, MDS, ATIE and EE should be stored so that condensation is not allowed to damage the electrical, instrumentation, and computer equipment.

\subsection{REFERENCES}

Conrad, R. B., 1996, WHC-SD-WM-OTP-213 Rev 0, Operability Test Procedure for the Light Duty Utility Arm in Tank T-106, Westinghouse Hanford 
Company, Richland, Washington.

Kiebe1, G. R., 1996, WHC-SD-ATP-004, Rev 0, LOUA Equipment Qualification Test Procedure, Westinghouse Hanford Company, Richland, Washington.

Kiebe1, G. R., 1996a, WHC-SD-TD-FRD-003 Rev 1, Functions and Requirements for the Light Duty Utility Arm Integrated System, Westinghouse Hanford Company, Richland, Washington.

T0-080-701, Mobile Deployment System Setup and Power, Westinghouse Hanford Company, Richland, Washington.

T0-080-704, Off-Norma7 Events: Recovery of the LDUA, Westinghouse Hanford Company, Richland, Washington. 
HNF-SD-WM-0TR-213, REV 0

\subsection{APPENDIX}

Field copy of the OTP.

Reference: WHC-SD-WM-0TP-213, Rev. 0 


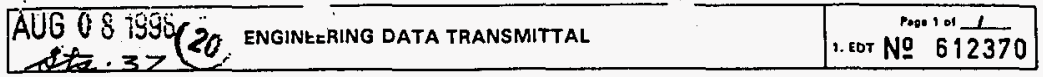

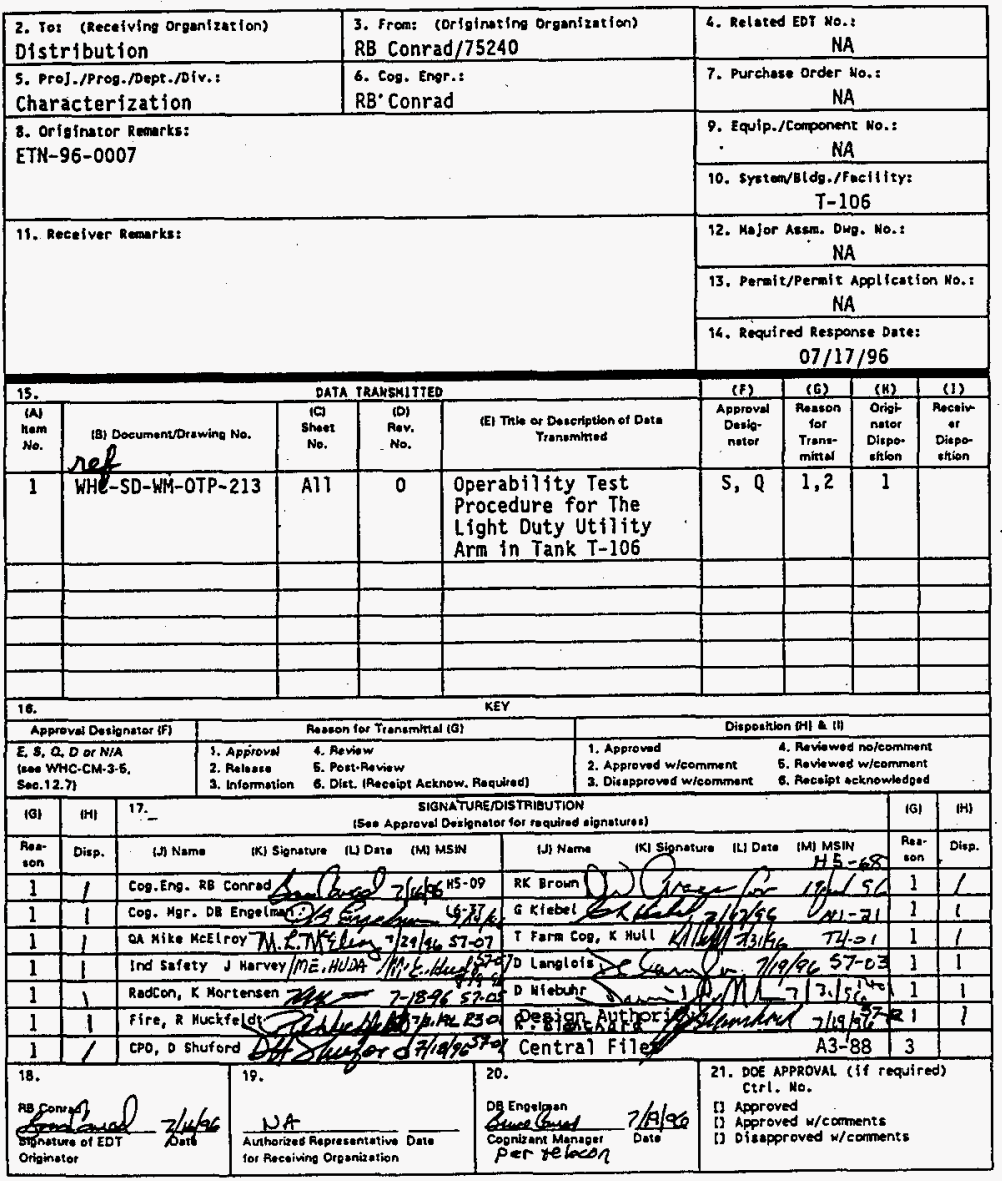

BD-7400-172-2 (04/94) GEF097

80.7400.172-1 
ref $W H C-S D-W H-O T P-213$, Rev, 0

\section{OPERABILITY TEST PROCEDURE FOR THE LIGHT DUTY UTILITY.ARM IN TANK T-106}

R. B. Conrad

Kestinghouse Hanford Company, Richland, WA 99352

U.S. Department of Energy Contract DE-ACO6-87RL10930

$\begin{array}{lll}\text { EDT/ECN: } & 158618 & \text { UC: } 2070 \\ \text { Org Code: } 75240 & \text { Charge Code: E44750 } \\ \text { BSR Code: } & \text { EW3120074 } & \text { Total Pages: } \text { I } 20\end{array}$

Key Words: Operability Test Procedure, OTP, Light Duty Utility Arm, LOUA

Abstract: The objective of this test is to demonstrate that the LDUA and alf its subsystems can be safely deployed in the field and operated as designed per the operating procedures. The objective is to successfully set up/assemble the LOUA and its subsystems at T-106, operate the LDUA inside of T-106, perform tasks with the, high resolution stereoscopic video system (HRSVS) and the gripper end effector (GEE) within that tank, and take down/remove all equipment from the tank farm.

ThADEKURK OISCLAJkER. Reference herefn to any specific coarnercial product, procese, or serviee by trade nane, tradenark, manufucturer, or otherwise, does not necessarlly constifute or imply its

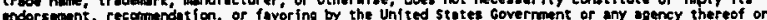
its contrectors or subcontractors.

Peinted in the United states of America. To obtain coples of this document, contect: Whe/ocs Document control Servicas, P.0. Sox 1970, Mailstop k6-08, Riehtand wh 99352, Phone (509) 372-2420; fax (509) 376.4989 .
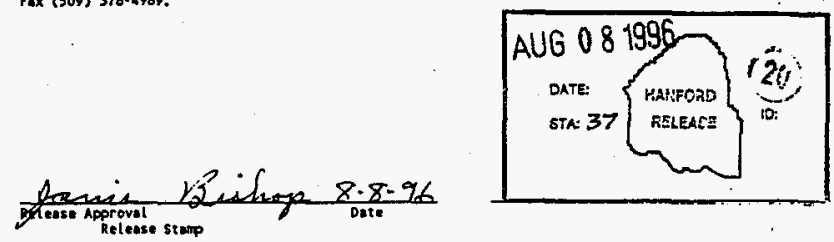

Approved for Public Release

A-6400-073 (10/95) GEF321 


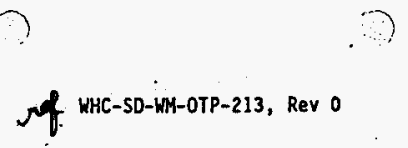

\section{OPERABILITY TEST PROCEDURE FOR THE LIGHT DUTY UTILITY ARM IN TANK T-106}

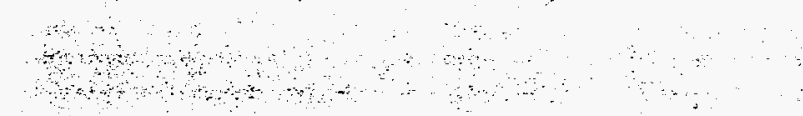

Author:.

R. B. Conrad

Westinghouse Hanford Company 


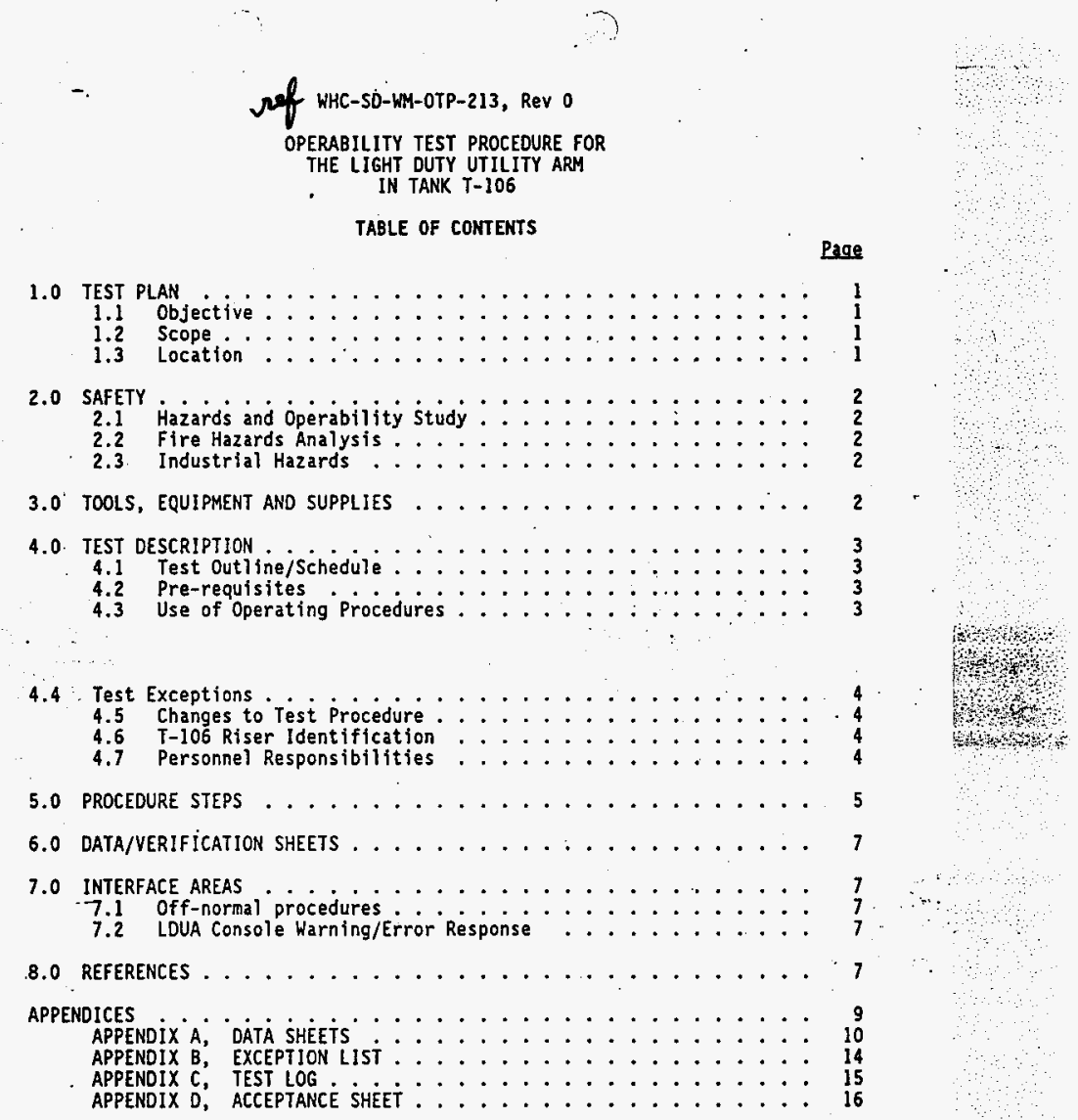

Page $\mathbf{i}$ 


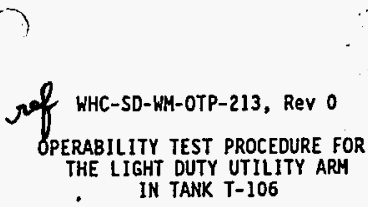

ACRONYMS

$\begin{array}{ll}\text { CEE } & \text { Characterization Equfpment Englneering } \\ \text { CPO } & \text { Characterization Project Operations } \\ \text { EE } & \text { End Effector } \\ \text { GEE } & \text { Gripper End Effector } \\ \text { HRSVS } & \text { High Resolution Stereo Video System } \\ \text { LDUA } & \text { Light-Duty Utility Arm } \\ \text { MDS } & \text { Mobile Deployment System } \\ \text { OAS } & \text { Optical Alignment Scope } \\ \text { OOVS } & \text { Operations Overview Video System } \\ \text { ORR } & \text { Operational Readiness Review } \\ \text { OCT } & \text { Operations Control Trailer } \\ \text { OTP } & \text { Operability Test Procedure } \\ \text { PCA } & \text { Procedure Change Authorization } \\ \text { PIC } & \text { Person In Charge } \\ \text { QE } & \text { Quality Engineer } \\ \text { TD } & \text { Test Director } \\ \text { TWRS } & \text { Tank Waste Remediation Systems } \\ \text { USQE: } & \text { Unreviewed Safety Question Evaluation } \\ \text { VAC } & \text { Volts Alternating Current } \\ \text { YPM } & \text { VerticaT Positioning Mast } \\ \text { WHC } & \text { Westinghouse Hanford Company }\end{array}$

Page $i 1$ 


\author{
WHC-SD-WM-OTP-213, ReV 0 \\ OPERABILITY TEST PROCEDURE FOR \\ THE LIGHT DUTY UTILITY ARM \\ IN TANK T-106
}

\subsection{TEST PLAN}

A test plan for this procedure has been prepared (Conrad, 1996) which describes the initial deployment of the Light Duty Utility Arm (LDUA) in Tank T-106. The LDUA Baseline System Description (Kiebel, 1996) defines the LDUA system and components. A number of functional support modules provide instrumentation and control capability. The LDUA provides the unique capability to enter a Hanford Site underground waste storage tank through existing $12^{\prime \prime}$ diameter risers and position a variety of instrumentation, video or other devices mounted to the end of the arm.

\subsection{Objective}

The objective of this test is to demonstrate that the LDUA and subsystems that are applicable to the T-106 deployment can be safely deployed in the field and operated as designed per the operating procedures. The objective is to successfully set up/assemble the LDUA and its sub systems at T-106, operate the LDUA inside of T-106, perform tasks with high resolution $\therefore$ stereoscopic video systen (HRSVS) and the gripper end effector (GEE) within

that tank, and take down/remove all equipment from the tank farm.

\subsection{Scope}

The scope of this test. is limited only to the initial deployment at tank T-106. The hot operability test procedure (OTP), commonly referred. to as the "hot test", will begin when the LDUA system installation on T-farm per the set up procedures begins. This OTP will end after the same equipment has been removed per the take down procedures. T-106 is a non watch listed tank. It is expected that several deployments in other tanks will be required before testing is complete. Operations has requested multiple deployments before final turnover to ensure that equipment operates correctly, procedures are accurate, and operators are comfortable with the system. orp's will be prepared for each test deployment which will evaluate changes to equipment and/or procedures.

\subsection{Location}

This test will be performed in Tank T-106 which is. a non watch list tank and is interim stabilized. It is an assumed leaker which is the reason it was pumped many years ago. This is also a reason it was selected for this test in that the high resolution camera would allow close observation of the tank wall. There is approximately 3 inches of waste in this tank (not counting the dished bottom). The waste surface is composed of damp peripheral sludge sloping inward to an irregular shallow center liquid pool.

Page 1 


\subsection{Hazards and Operabilịty Study}

A hazards and operability study and a safety assessment have been performed (Heubach, 1996a). The results show that: (a) the risk associated with the hot test of the LDUA in tank 241-T-106 does not significantly increase the overall risk of operating the Tank Farms; and, (b) no new controls or unique application of existing controls need to be implemented for an acceptably safe test of the LDUA in 241-T-106. A USQE was prepared that reflects this result (Heubach, 1996b).

\subsection{Fire Hazards Analysis}

A Fire Hazards Analysis (FHA) has been prepared (Huckfeldt, 1996). Two findings were identified, 1) the procedure that places components in the farm must be reviewed and approved by Fire Protection Engineering and 2) emergency/recovery must be addressed in the operating procedures.

\subsection{Industrial Hazards}

Since $T-106$ is a non watch 7 ist tank, the most credible hazards are industrial and radiological in nature. Procedures verification and training will be performed prior to the test to minimize the chance of injury or overexposure to radiation/contamination. off-normal procedures will be

topepared to address situations such as loss of power and inclement weather.

Test personnel should exercise proper work habits including use of Personal Protective Equipment while performing this test procedure in addition to that required by the Radiation Work Permit. The following potential hazards exist during various sections of the test:

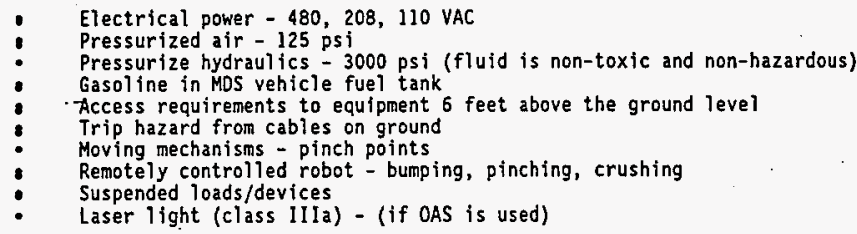

\subsection{TOOLS, EQUIPRENT AND SUPPLIES}

An equipment layout sketch has been prepared that will be included in the work package. This sketch will identify the location where each component will be staged inside or outside of T farm. Corridors will also be identified for cable runs. 
- $\quad$ WHC-SD-WM-OTP-213, Rev 0

A gama detector may be required during the Gripper End Effector (GEE) demonstration test.

The LOUA operating procedures identify tools, equipment, and supplies normally required for deployment.

\subsection{TEST DESCRIPTION}

\subsection{Test Outiline/Schedule}

The following is an estimate of the durations to perform each major task. The current estimate is to be able to begin staging in late August. The goal is to be out of the farm by end of September.

Stage subsystem equipment - 4 to 5 days

Connect and energize - one day

Align MDS, connect, energize - 2 to 3 days

Perform in-tank demonstrations - 5 days

De-energize, disconnect - 2 to 3 days

Remove from Farm - 3 days

\subsection{Pre-requisites}

The LOUA Equipment Qualification Test Procedure, (Kiebel, 1995) must be completed prior to staging any equipment into $T$ farm.

Follow all pre-requisites identified in the operating procedures.

Dome loading controls will be included in work package.

\subsection{Use of Operating Procedures}

This test will utilize the following LDUA operating procedures;

- T0-080-700, LDUA Subsystem Staging/Interconnection/Energization

- T0-080-701, Mobile Deployment System Setup and Power

- T0-080-702, LDUA In-Tank Operations

- T0-080-703, LDUA Systen Power Down, Decon, and Equipment Remova?

- TO-080-704, Off-Normal Events: Recovery of the LDUA

These procedures will be released prior to performance of this test.

Page 3 


\subsection{Test Exceptions \\ ref WHC-SO-WH-OTP-213, Rev 0}

Editorial and administrative exceptions noted during the execution of the OTP shall be recorded in the test log (Appendix $C$ ) and the exception sheet (Appendix B). If an exception is noted, testing must be suspended unt 11 approval to continue is obtained from the test director and PIC. Approval to continue shall be documented by signature in the test $10 \mathrm{~g}$ and test exception sheet.

\subsection{Changes to Test Procedure}

A master copy of this test procedure document shall be maintained by the. Test Director. Field copies may be made and distributed as desired to

facilitate testing. The OTP shall be controlled in accordance with WHC-CM-61. EP-2.2 by ECN for any changes that affect operating facility safety, function, or performance and that compromise or influence test data. Any change to any of the plant operating procedures, T0-080-700 - 704, shall be controlled through use of the PCA process.

\subsection{T-106 Riser Identification}

Riser prep/inspection work package WS-96-00052/W was performed. The following risers will be used during this test.

The LDUA will be deployed into riser $\$ 6$.

The overview camera will be deployed into riser $\$ 3$ (riser $* 3$ is the primary riser, but numbers $1,2,4,5$ or 7 could al so be used at the PIC's discretion).

The gamma detector (if used) will be deployed into riser $\# 5$, or \#7 depending on field conditions.

\subsection{Persomnel Responsibilities}

Actual names of the following positions will be identified at the prejob briefing and will be posted in the Operations Control Trailer (OCT) during the test. Training will be ongoing right up till start of the test.

Test Director -The TD (from CEE) is responsible for overall performance of test, approves of test exceptions and corrective actions (appendix $B$ ) and approves test acceptance sheet (appendix D). Also is responsible for ensuring that the test $\log$ is kept up to date.

LDUA Supervisor - Has demonstrated to the Remote System and Sensor Applications (RSSA) organization a high level of knowledge and understanding of the system and operating software. The supervisor can perform software diagnostic tasks if necessary. The RSSA LDUA design authority will act as LDUA supervisor if necessary. 
$\therefore \quad$ Nf WHC-SD-WM-OTP-213, Rev 0

Person In Charge - The PIC (from TWRS CPO) is responsible for coordinating all field activities, operators, crafts, and support personnel. PIC shall record data (or his designee), initial and date test steps, approve of exceptions and corrective actions (appendix $B$ ) and sign test acceptance sheet (appendix D).

LDUA Operator - Personnel who have been qualified to operate or perform certain LDUA equipment and tasks.

Facility Cognizant Engineer - Reviews and approves changes to test procedures to assure they are consistent with facility requirements.

Quality Engineer - Reviews test documentation and approves test acceptance sheet (appendix D).

Gamma Detector Operation - All equipment, instrumentation, and detector operation is the responsibility of Special Anajytical studies. The LOUA simply provides a means to move the detector to multiple in-tank locations.

\subsection{PROCEDURE STEPS}

Nore: It is possible that the gamma detector may be eliminated from the test. If so, it will be documented as "comment only" in the exceptions.

5.1 Stage, interconnect cabling and hoses, and energize all subsystem equipment per procedure T0-080-700 and the equipment layout sketch

(procedure T0-080-700 does not include the Mobile Deployment System) AND identify in the test $\log$ (appendix C) any deficiencies/improvements that can be made).

NOTE: The overview video camera will be deployed in a riser which is on the opposite side of Tank T-106 from riser $\$ 5$ where the LDUA will be deployed. Riser 3 is the primary riser for camera deployment, PIC may elect Riser $1,2,4,5$ or 7 if field conditions require.

NOTE: If field condition requires, PIC may elect to deploy a second overview camera to enhance operation and safety.

5.2 Confirm the accuracy of the world model by visualiy comparing it to the overview video display and record results in data sheet for step 5.2 (appendix A).

5.3 Position the MDS over riser $\$ 6$ per procedure T0-080-701. Record inclinometer readings prior to traversing the riser, minimum distance readings from. lasers if traverse is successful (if use OAS) and distance traveled if attempt is not successful. Record applicable information on data record sheet for step 5.3 (Appendix A).

5.4 Install the HRSVS onto the LDUA per T0-080-702, section 5.1. 


\section{. \\ - $\quad$ ref WHC-SD-WM-OTP-213, Rev 0}

5.5 Enter tank per T0-080-702, section 5.3.

5.6 Perform tank inspection of the tank wall, dome, riser, and waste using the HRSVS per procedure 70-080-702, section 5.4. Record information requested on data sheet for step 5.6 (Appendix $A$ ).

5.7 Retract from tank per procedure T0-080-702, section 5.6. .

5.8 Remove the HRSVS from the LOUA per procedure T0-080-702, section 5.9.

5.9 Install GEE per procedure 70-080-702, section 5.1.

5.10 Install the gama detector in riser $\$ 5$ or riser $\# 7$ (depending on field conditions and riser avallability) to a depth of about 25 feet below the top of riser flange. This will allow the GEE to grasp the detector.

MOTE: The gama detector will be installed per work instruction in the work package. It sends signals to a computer that will be located in the overview camera truck via a coax cable.

5.11 Deploy GEE into tank riser $\$ 6$ per procedure T0-080-702, section 5.3.

5.12 Grasp the gamma detector with the GEE per procedure TO-080-702, section 5.5.

CAUTLON: - Steps 5.13 to 5.16-require that an HPT "manage" the gamma detector cable until the GEE releases it and it can be removed from the tank.

5.13 Retrace the path taken by the HRSVS AND collect and record data as required on data sheet for step 5.13 (Appendix A).

5.14 Retract GEE and gama detector to start point elevation (25 feet below riser flange).

5.15 Release gamma detector from the grasp of the GEE.

HOTE: In the following step the gamma detector will be removed from the tank per work instructions in the work package.

5.16 Retract gamma detector from tank and replace flange.

NOTE: In the following step, the capability of the LDUA to move intank objects will be demonstrated. PIC shall position overview camera system as required to optimize view.

5.17 If a discarded manual tape is within reach then move LDUA to position the GEE to pick up a portion of the tape about one foot high, move 


\footnotetext{
- NCWC-SO-WH-OTP-213, Rev 0

laterally one foot and return tape to waste surface (per T0-080-702, section 5.5).

5.18 Retract GEE from tank per procedure T0-080-702, section 5.6.

5.19 Remove GEE per procedure T0-080-702, section 5.9.

5.20 De-energize and take down the LOUA system per procedure T0-080-703.
}

\subsection{DATA/VERIFICATION SHEETS}

All results and observations called for by this test procedure will be recorded on copies of the appropriate test data sheets that are included in appendix $A$ of this document. Additional information (test log, exception records, etc.) as called for elsewhere in this document shall be recorded on copies of the various supplemental record sheets in the appendices. Video tapes will be made during the test procedures and will be considered to be test results. These video tapes shall be properiy labeled and stored and noted in the test iog. The Test Director shall maintain custody of all test records whenever they are not actually being used during testing.

An operabllity test report shall be prepared and issued as a WHC Supporting Document. This report will describe and summarize testing activity and will include copies of test data sheets and supplemental record sheets.

\subsection{INTERFACE AREAS}

\section{1 off-normal procedures}

Refer to procedure T0-080-704 for all off-normal procedures.

\subsection{LDUA Console Warning/Error Response}

The LOUA diagnostic software will provide warning and error messages to the operator. Warnings indicate a limit is about to be reached and 4 levels of errors indicate a limit has been surpassed. The following operator responses are required for each case (1isted in ascending order of critical error, least critical to most critical).

Warning message - Operator continues at his own discretion.

Level 4 Error message - Operator obtains PIC approval before continuing.

Level 3 Error message - Operator obtains PIC and Test Director approval before continuing.

Leve1 2 and 1 Error messages - Operator obtains PIC, Test Director and LDUA Supervisor approval before continuing. 


\section{fof WHC-SD-WM-OTP-213, Rev 0
8.0 REFERENCES}

Conrad, R. B., 1996, WHC-SD-WM-TP-435 Rev 0, Test Plan for Light Duty Utility Ara (LOUA) Operability Test Procedure (OTP), Westinghouse Hanford Company, Richiand, Washington.

Heubach, E. C. (1996a), WHC-SD-WM-SAD-038 Rev 0, Safety Assessment for the Hot Test of the Light Duty Utility Arm in Hanford Tank 241-T-106, Westinghouse Hanford Company, Richland, Washington.

Heubach, E. C. (1996b), TF-96-0171, Unreviewed Safety Question Evaluation for the Hot Test of the Light Duty Utility Arm in Hanford Tank 241-T-106, Westinghouse Hanford Company, Richiand, Washington.

Huckfeldt, R. A., 1996, WHC-SD-WM-FHA-018, Rev 0, Fire Hazards Evaluation for Light Duty Utility Arm System, Westinghouse Hanford Company, Richland, Washington.

KJebel, G. R. (1996a), WHC-SD-TD-ER-005 Rev 1, Light Duty Utility Ara Baseline System Description, Westinghouse Hanford Company, Richland, Washington.

Kiebe1, G. R. (1996b), WHC-SO-ATP-004 Rev 0, LOUA Equipment Qualification Test Procedure, Westinghouse Hanford Company, Richland, kashíngton.

T0-080-700, LOUA Subsystem Staging/Interconnection/Energization, Westinghouse Hanford Company, Richland, Washington.

T0-080-701, Hobile Deployment System Setup and Power. Westinghouse Hanford Company, Richland, Washington.

T0-080-702, LDUA In-Tank Operations, Westinghouse Hanford Company, Richland, Washington.

T0-080-703, LDUA System Power Down, Decon, and Equipment Removal, Westinghouse Hanford Company, Richland, Washington.

T0-080-704, Off-Normal Events: Recovery of the LOUA, Westinghouse Hanford Company, Richland, Washington.

WHC-CM-6-1, St andard Engineering Practices, Westinghouse Hanford Company, Richland, Washington. 

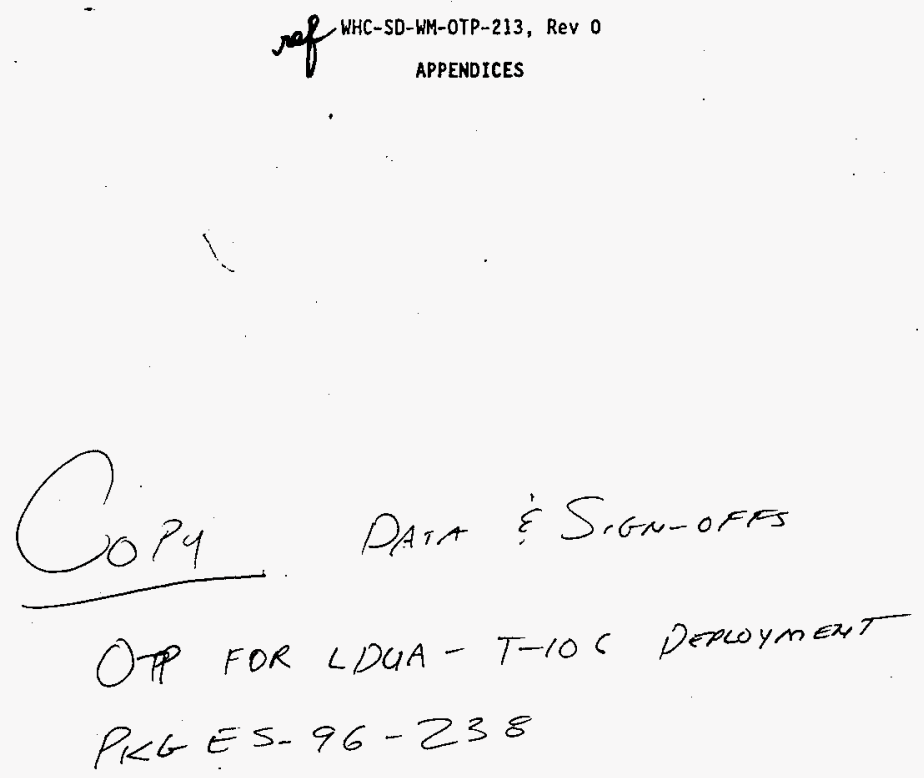

Page 9 


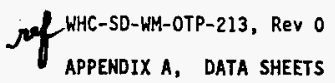

Data Record for Step 5.2

World Model comparison with actual video display from overview camera.

Acceptable response is yes. A yes response means that there are no

obstacles in the tank that are not on the world mode) (example of $a$ no

response would be if an air ifft circulator was actually present in a riser

that the world model did not show).

\begin{tabular}{|c|c|}
\hline Component & Obseryations \\
\hline $\begin{array}{l}\text { World Model } \\
\text { accurate? }(y / n)\end{array}$ & Tape $10 \quad T-106 \neq 5$ \\
\hline
\end{tabular}

comments: See Exception tt3. RBC $9 / 2>/ 26$

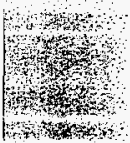

Page 10

cory - 
WHC-SD-WM-OTP-213, Rev 0

Data Record for Step 5.3

\begin{tabular}{|c|c|c|c|}
\hline \multicolumn{4}{|c|}{$\begin{array}{l}\text { WpH Algniment process data (acceptable result: full traverse without } \\
\text { contact ing } 1 \text { ser) }\end{array}$} \\
\hline 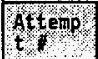 & Inclinometer & $\begin{array}{l}\text { Minimum clearance } \\
\text { Readings (if oAs used) }\end{array}$ & Result \\
\hline Attemp & $\begin{array}{l}\text { Rol1 }+.56 \text { (deg } \\
\text { Pitch }-.16 \text { (de } \\
\text { g) }\end{array}$ & 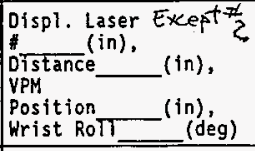 & 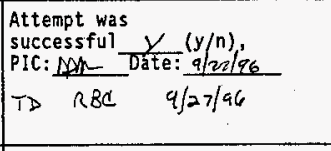 \\
\hline $\begin{array}{l}\text { Attemp } \\
\text { try }\end{array}$ & 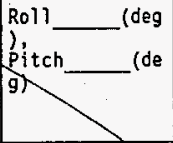 & $\begin{array}{l}\text { Displ. Laser } \\
\text { \# (in), } \\
\text { Distance } \\
\text { VPM } \\
\text { Position } \\
\text { Wrist RoT__in), (deg) }\end{array}$ & $\begin{array}{l}\text { Attempt was } \\
\text { successfut Date: } \\
\text { PIC: }\end{array}$ \\
\hline Attemp & $\begin{array}{l}\text { Roll } \\
\text { Pitch } \\
\text { g) }\end{array}$ & $\begin{array}{l}\text { Displ. Laser } \\
\text { (in), (in), } \\
\text { Distance } \\
\text { VPH } \\
\text { Position (in), } \\
\text { Wrist RoTl_eg) }\end{array}$ & $\begin{array}{l}\text { Attempt was } \\
\text { successful } \\
\text { PIC: Date }\end{array}$ \\
\hline $\begin{array}{l}\text { Attemp: } \\
t+4\end{array}$ & $\begin{array}{l}\text { Roll ____ (deg } \\
\text { Pitch___ (de } \\
\text { g) }\end{array}$ & $\begin{array}{l}\text { Displ. Laser } \\
\text { \# (in), (in), } \\
\text { Distance } \\
\text { VPH } \\
\text { Position (in), } \\
\text { Wrist RoT___(deg) }\end{array}$ & $\begin{array}{l}\text { Attempt was } \\
\text { successful } \\
\text { RIC: Dat }\end{array}$ \\
\hline Attemp & $\begin{array}{l}\text { Roll ___ (deg } \\
\text { Pitch } \\
\text { g) }\end{array}$ & $\begin{array}{l}\text { Displ. Laser } \\
\# \\
\text { Distance (in), (in), } \\
\text { VPM } \\
\text { Position (in), } \\
\text { Wrist Roll__(deg) }\end{array}$ & $\begin{array}{l}\text { Attempt was } \\
\text { successful } \\
\text { PIC: Date }\end{array}$ \\
\hline
\end{tabular}

Page 11

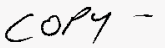




\begin{tabular}{|c|c|}
\hline & Data Record for Step 5.6 \\
\hline \multirow{2}{*}{\multicolumn{2}{|c|}{$\begin{array}{l}\text { HRSVS In-Tank Video Survey performance (acceptable result: answer yes to all } \\
y / n \text { questions). } \\
\text { Clear - the image is in focus? } \\
\text { Stable - the image has no vibration? } \\
\text { Free of Distortion = the image is not skewed in anyway? } \\
\text { Free of Interference }=\text { the image has no ines or static? } \\
\text { Image free of doubling }=\text { only one image is seen with } 3 d \text { glasses on? } \\
\text { Image provides depth perception = 30 with glasses on? }\end{array}$}} \\
\hline & \\
\hline $\begin{array}{l}\text { Yideo Tape } \\
\text { Information } \\
\end{array}$ & Tape ID $T-106 \neq 4 \quad$ PIC:Mq_ Date: $9 / 27 / 96$ \\
\hline Feature of T-106 & Observation \\
\hline Riser/Dome interface & 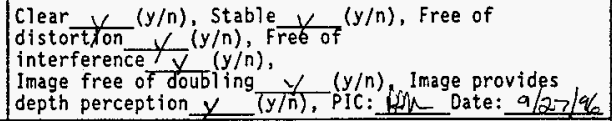 \\
\hline $\begin{array}{l}\text { Vertical Wall scan } \\
\text { (top to bottiom of } \\
\text { side wall) }\end{array}$ & 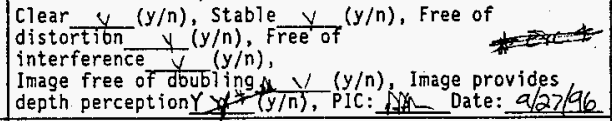 \\
\hline Wall/Waste Interface & 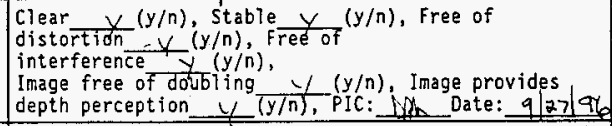 \\
\hline $\begin{array}{c}\text { Waste Surface } \\
\text {-- }\end{array}$ & 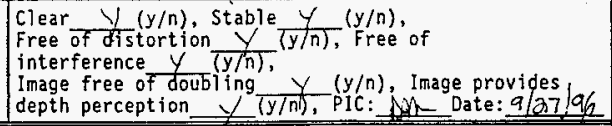 \\
\hline Video Tape Record & $\begin{array}{l}\text { Clear }(y / n), 5 \text { table }(y / n), \text { Free of } \\
\text { distortion }(y) n) \text {, Free of } \\
\text { interference }(y / n), \\
\text { video image during tovement is smooth and } \\
\text { stable }\end{array}$ \\
\hline
\end{tabular}

Page 12

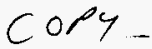


Nof WHC-SD-WM-OTP-213, Rev 0

Data Record for Step 5.13

GEE performance and gamma'scan results. (acceptable result: answer yes to all $y / n$ questions. Gamma reading for information only).

clear - the image is in focus?

stable = the image has no vibration?

Free of Distortion = the image is not skewed in anyway?

Free of Interference = the jmage has no jines or static?

Image free of doubling = only one image is seen with $3 \mathrm{~d}$ glasses on?

Image provides depth perception = 3D with glasses on?

\begin{tabular}{|c|c|}
\hline $\begin{array}{l}\text { Video Tape } \\
\text { Information }\end{array}$ & Tape ID T-106 $\Leftrightarrow 74 B$ PIC: IXM Date: $9 / 30$ \\
\hline Feature of $T-106$ & $\angle e \times c e A+4 \quad R B C / 30 / a c$ \\
\hline Riser/Dome interface & 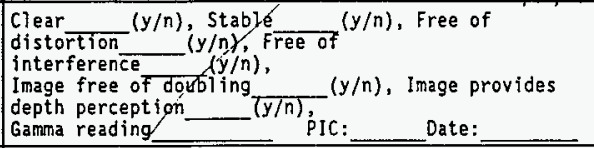 \\
\hline $\begin{array}{l}\text { Vertical Wall Scan } \\
\text { (top to bottom of } \\
\text { side wall) }\end{array}$ & 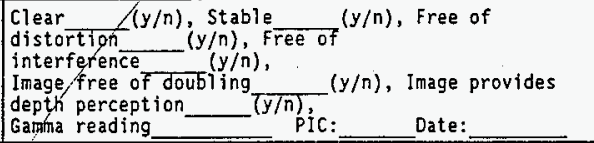 \\
\hline Wall/Waste Interface & 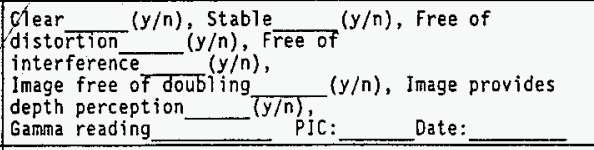 \\
\hline & $\begin{array}{l}\text { Clear }(y / n), \text { Stable }(y / n) \text {, } \\
\text { Free of distortion } \overline{(y / n)} \text {, Free of } \\
\text { interference } \\
\text { Image free of doubiling } \\
\text { depth perception }(y / n) \text {, Image provides } \\
\text { Gamma reading }\end{array}$ \\
\hline Video Tape Record & 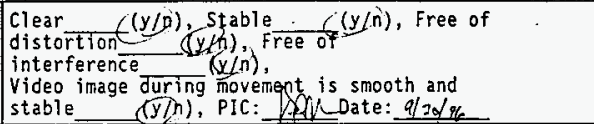 \\
\hline
\end{tabular}

Page 13

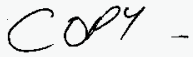


ref WHC-SD-WM-OTP-213, Rev 0
APPENDIX B, EXCEPTIOH LIST
Sheet $L$ of $\perp$ Test Exception Sheets

\begin{tabular}{|c|c|c|c|}
\hline \# & Description & Resolution & Approvals \\
\hline 1 & $\begin{array}{l}\text { Gamma detector } \\
\text { not used. } \\
\text { steps } 5.10,5.12\end{array}$ & $\begin{array}{l}\text { accepted. No action } \\
\text { required. } \Delta T P \text { allourd } \\
\text { for this possibility }\end{array}$ & 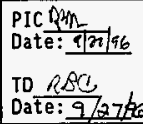 \\
\hline 2 & $\begin{array}{l}\text { OAs not used so } \\
\text { Datasheet } 5,3 \text {. not } \\
\text { \& lled out for "liminimg } \\
\text { clearance readings" }\end{array}$ & $\begin{array}{l}\text { acceptod. no aotion } \\
\text { requcrod. OTP a llowed } \\
\text { for This passibllity. }\end{array}$ & 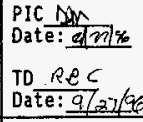 \\
\hline 3. & $\begin{array}{l}\text { - world model does } \\
\text { not show } T C \text { tree in } \\
R \text { R. also manhole } \\
\text { flush we dome rather thab } \\
\text { penetraying. }\end{array}$ & $\begin{array}{l}\text { Noted. No action. } \\
\text { required at inhistime. } \\
\text { will tako into account } \\
\text { when perform intank } \\
\text { operation }\end{array}$ & 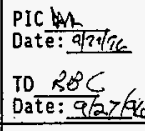 \\
\hline$\nabla^{5}$ & $\begin{array}{l}\text { Enraf not shown } \\
\text { on Riser } 1\end{array}$ & $\$$ sea aboul & 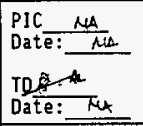 \\
\hline 4 & $\begin{array}{l}\text { Did not retrace teps } \\
\text { path of Hesus } \\
\text { - }\end{array}$ & $\begin{array}{l}\text { accepted. not roquiled } \\
\text { because the gamma. } \\
\text { detedor not deployed. } \\
\text { (see except 1). only } \\
\text { neet to pick up take }\end{array}$ & $\begin{array}{l}\text { PIC AdAn } \\
\text { Date: } 9130 / 96 \\
\text { TD } R B C \\
\text { Date: } 9 / 70 / 96\end{array}$ \\
\hline
\end{tabular}

Page 14

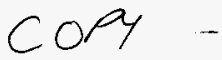


sif WHC-SD-WM-OTP-213, Rev 0

APPENDIX C, TEST LOG

Sheet 1 of $10 \log$ sheets

\begin{tabular}{|c|c|c|}
\hline Date/Time & Comments & Initials \\
\hline $9 / 26 / 21^{30}$ & Set up penformed lar weeh. Powiche & EBC \\
\hline & effecury inpromente unflude betru & \\
\hline & cable reels (Powes \& fiher dotic). & \\
\hline & lowith alogrmut performed tonights. & \\
\hline & sotis untalled at alout $6: 30^{\circ \mathrm{m}}$ or so, & \\
\hline $9 / 2790$ & Pre ot complet Notes Gamma detectar & $R B C$ \\
\hline & not used for this deploymunt OAS & \\
\hline & notused for this destymanta OTP & \\
\hline & allowed for borh. Documentod as & \\
\hline & exceplians 102 . No action & \\
\hline & requeste. & \\
\hline 930 & Nate. loghting from vitis & 1.2. \\
\hline & is excoleme no nood for additional & \\
\hline & $40 h+5$. & \\
\hline 947 & Note: LDU4 in $R 6$, vot is in $R 3$ & RBC \\
\hline 1032 & Penetrated bottom of riser ( $I / 0$ ) & Rer \\
\hline & orsecuation $\rightarrow$ tight an $-x+y-y$ & \\
\hline- & of EE(HRSNS) & \\
\hline
\end{tabular}

Items to be recorded in the test $\log$ will consist of, as a minimum,

dates/times for procedure start and stop, documentation of test exceptions, and commentary on any issues observed during testing. Each test log entry shall be signed and dated by the person making the entry. 
WHC-SD-WM-OTP-213, Rev 0

APPENOIX C, TEST LOG

Sheet 2 of $1 \log$ sheets

\begin{tabular}{|c|c|c|}
\hline Date/Time & Comments & Initials \\
\hline$9 / 2 7 \longdiv { 1 0 3 5 }$ & Outer tube penetrates top of & $B R C$ \\
\hline & crser obarrue spaco on all & \\
\hline & sider (mastan $+x$ ). ARM & \\
\hline$\cdots$ & suecesenely in tank. & \\
\hline $9.7 / 1100$ & in tank inpectian & $R B C$ \\
\hline & Note: streo not in coler. & \\
\hline 1200 & Buobe for funch. & \\
\hline & & \\
\hline $22^{2} / 1250$ & Resuned unpection & RBC \\
\hline & Not: Aolor is now back on & \\
\hline & stereo. Prollem suspected & \\
\hline & to be in octpon of side by side & \\
\hline & 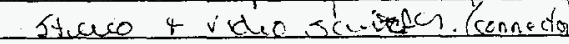 & \\
\hline 4271320 & Stase wared not appecul & $R B C$ \\
\hline & untill uve rebored SDAS. & \\
\hline 1 & & \\
\hline & & \\
\hline & & \\
\hline
\end{tabular}

Items to be recorded in the test $\log$ will consist of, as a minimum, dates/times for procedure start and stop, documentation of test exceptions, and commentary on any issues observed during testing. Each test log entry shall be signed and dated by the person making the entry. 
fof WHC-SO-WM-OTP-213, Rev 0
APPENDIX C, TEST LOG

Sheet 3 of $\log$ sheets

\begin{tabular}{|c|c|c|}
\hline Date/Time & Comments & Initials \\
\hline \multirow[t]{4}{*}{$9 / 27 \cdot 45$} & Qsypr $=I+0=21.5$ "waten & RBC \\
\hline & wit no movement. & \\
\hline & Rumat of times to rnoped. & \\
\hline & Won in retiaction & \\
\hline & & \\
\hline \multirow{4}{*}{$x \mid 27,42$} & ìcli uculd & $R B C$ \\
\hline & becele to manitor puige premine & \\
\hline & white resating (moruing t the arnd & \\
\hline & HPM on the samo screen (Vpm/Ldua ) & \\
\hline 1 & & \\
\hline \multirow[t]{8}{*}{1430} & Top clawe antacted Botion of uses & RRC \\
\hline & Copta tape tore at Air fickich & \\
\hline & (Not contaminated & \\
\hline & Qbelaur sboulidu yaw & \\
\hline & Dako aboke sh.cam! lighys & \\
\hline & - boot tere at top of top clalmp & \\
\hline & bitsures top e loup and cluet & \\
\hline & tapa $11 y_{2}$ foot lengt $h$ & \\
\hline
\end{tabular}

Items to be recorded in the test $\log$ will consist of, as a minimum,

dates/times for procedure start and stop, documentation of test exceptions, and commentary on any issues observed during testing. Each test log entry shall be signed and dated by the person making the entry. 
Nof WHC-SD-WM-OTP-213, ReV 0
APPENDIX C, TEST LOG

Sheet 4 of $\log$ sheets

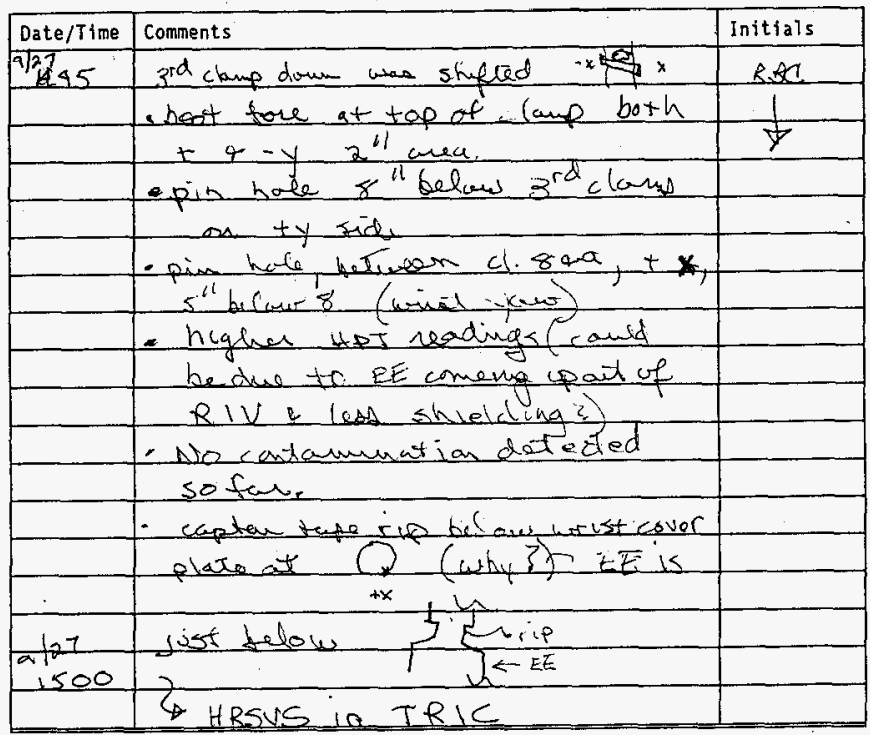

Items to be recorded in the test log will consist of, as a minimum, dates/times for procedure start and stop, documentation of test exceptions, and commentary on any issues observed during testing. Each test log entry shall be signed and dated by the person making the entry. 
HNF-SD-WM-0TR-213, REV 0

\begin{tabular}{|c|c|c|}
\hline & Sheet 5 of & _ $\log$ sheets \\
\hline Date/Time & Comments & Initials \\
\hline $9 / 27 \quad 1503$ & Shut To RU. & $R B<$ \\
\hline \multirow[t]{6}{*}{$867 \quad 15 \cdot 10$} & Reworing HRSVS. & PBC \\
\hline & TRC leias clean so OK & $\frac{1}{ \pm}$ \\
\hline & to open door w/Blves. & \\
\hline & Nate:-need to improve & \\
\hline & Rov handle access 55 & \\
\hline & provide puenmatic/motor & \\
\hline \multirow[t]{4}{*}{.} & ophato? & \\
\hline & - bouter deiegu for & \\
\hline & MEEES caple hoist? & \\
\hline & (ballery operated houst?) & \\
\hline \multirow{3}{*}{1521} & & \\
\hline & HRSVS clean 4 neaned plared & $20 x$ \\
\hline & in bag a in cantaunes: & \\
\hline \multirow[t]{2}{*}{$967 \quad 1600$} & Shrodown for the day & $R P C$ \\
\hline & & \\
\hline
\end{tabular}

Items to be recorded in the test $\log$ will consist of, as a minimum, dates/times for procedure start and stop, documentation of test exceptions, and commentary on any issues observed during testing. Each test log entry shall be signed and dated by the person making the entry.

Page 15

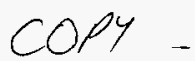


WHC-SD-WM-OTP-213, ReV 0

APPENDIX C, TEST LOG

Sheet 6 of _ $\log$ sheets

\begin{tabular}{|c|c|c|}
\hline Date/Time & Comments & Initials \\
\hline $1 / 30 / 900$ & began restart / boot op of system & RPC \\
\hline $60 / 1030$ & began re-establishment of & ePC \\
\hline & alunmeates pitch at $=16$ & \\
\hline dso 1100 & Notesfrom diast Fiddoy events: & QDC \\
\hline & - Sh ft in a lignment ocutred. & \\
\hline & wlile inside tank. (pitch axis) & \\
\hline & - : Pitch readings & \\
\hline & . Frimarn $==16$ & \\
\hline & - Eri afternoon $=-.16$ & \\
\hline & - End ofday $\left(F_{r i}\right)= \pm .19$ & \\
\hline & - Monday morn $=00$ & \\
\hline & - observations & \\
\hline & Painters tad painted & \\
\hline & Drate surfares & \\
\hline & - ipar predicted some & \\
\hline & deflection due to Therm & I defles \\
\hline
\end{tabular}

Items to be recorded in the test $\log$ will consist of, as a minimum, dates/times for procedure start and stop, documentation of test exceptions, and commentary on any issues observed during testing. Each test log entry shall be signed and dated by the person making the entry.

Page 15

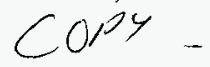


Sheet 7 of $\log$ sheets

\begin{tabular}{|c|c|c|}
\hline Date/Time & 2 lacked. & Initials \\
\hline 9601000 & (contikved) pitch ${ }^{4}$ moved $2-16$ to -.018 & $\notin B C$ \\
\hline & Conclusion: Resule of discussion & ! \\
\hline & hetween Pick Roymond PIC, hane & \\
\hline & Langlois, Bouce Conrad Gary krebel, & $\nabla$ \\
\hline & chis smith decided to proceed & \\
\hline & with GEE deployment abert@+L & \\
\hline & $\operatorname{plan} \frac{\pi}{15+0}$ & \\
\hline 1220 & Bowered into tank, GEE oT & \\
\hline & Dottom of risertpitch $=-.003$ & \\
\hline 1233 & $12 \pm=046$ & \\
\hline 1236 & $p=-002$ (36" from waste) & \\
\hline 1243 & $12 \geq-.002$ & \\
\hline 1248 & $P=-\cos$ & \\
\hline 1253 & $p=+.009$ & oats \\
\hline 1259 & dropped tape by spenin & \\
\hline & burs. began retraction & \\
\hline 1301 & $p=-.002$ Tere deces rad lowor $=$ & () \\
\hline & Detect $1,2,4$ zero $=0-85 \quad 3 \rightarrow$ zero $=85$ & $|7|-34 \mid$ \\
\hline
\end{tabular}

Items to be recorded in the test $\log$ will consist of, as a minimum, dates/times for procedure start and stop, documentation of test exceptions, and commentary on any issues observed during testing. Each test log entry shall be signed and dated by the persan making the entry. 
WHC-SD-WM-OTP-213, ReV 0

APPENDIX C, TEST LOG

Sheet $\underline{8}$ of _ $\log$ sheets

\begin{tabular}{|c|c|c|}
\hline Date/Time & Comments & Initials \\
\hline $9 / 3 / 303$ & $p= \pm .005$ & RBC \\
\hline 11305 & $R=+012$ & \\
\hline 1307 & $15 x$ clamp eleared w/ no hanging." & \\
\hline & E operafous apply push motion & \\
\hline & on mast via telce fo facilitate & \\
\hline & clamp clearance of iwer ok so & \\
\hline & for. & \\
\hline 1311 & Rad luns all zeros, GEE & \\
\hline & about 10 feet from botlom of & \\
\hline & riser & \\
\hline 135 & $p= \pm .02$ & \\
\hline 1312 & ead zeroon Rod defect. $=0$ & \\
\hline & CEE $N 5-10^{\prime}$ belsw TRLC & \\
\hline 1320 & Fed $=250$ counts Rad det $3 x 11$ zen & \\
\hline & when SEE in TRTC & \\
\hline 1321 & $p=+.02$ & \\
\hline$\nabla<326$ & Yugers of GEE $=1$ initial smoar $30 \mathrm{~m}$ & \\
\hline & & \\
\hline
\end{tabular}

Items to be recorded in the test log will consist of, as a minimum, dates/times for procedure start and stop, documentation of test exceptions, and commentary on any issues observed during testing. Each test log entry shall be signed and dated by the person making the entry.

Page 15

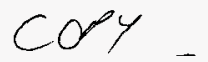


NF WHC-SO-WH-OTP-213, ReV 0
APPENDIX C, TEST LOG

Sheet 9 of _ $\log$ sheets

\begin{tabular}{|c|c|c|}
\hline Date/Time & Comments & Initials \\
\hline 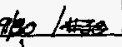 & Nesies on Fridays in-tank inspection & RSC \\
\hline & with Hesus & \\
\hline & - Drip flashing over top of iner- & \\
\hline & did net Notice signs of Atar & \\
\hline & paper stain". & \\
\hline & - tocteline a saw nothing of & \\
\hline & inyerost. & \\
\hline & - Stiffener. - Saw 2 peer welds & \\
\hline & - forlowad horcacantal \& vertical & \\
\hline & welds wall wat & (e) \\
\hline & * near botlou of tankion & \\
\hline & - vertical weld noficed fits & \\
\hline & Mweld as deap as weld is & \\
\hline & wide $\left(3 / 8 x^{\prime \prime} \operatorname{sop}\right)$. & \\
\hline & - No water decon wos requers & \\
\hline 1331 & $\operatorname{to19}=$ pitch & \\
\hline 1334 & Notes confinued: would te rice & \\
\hline & to have measuroment eapabilik & \\
\hline
\end{tabular}

Items to be recorded in the test $\log$ will consist of, as a minimum, dates/times for procedure start and stop, documentation of test exceptions, and commentary on any issues observed during testing. Each test log entry shall be signed and dated by the person making the entry.

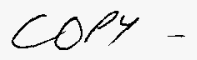


WHC-5D-WM-OTP-213, ReV 0

APPENDIX C, TEST LOG

Sheet 10 of $\ldots \log$ sheets

\begin{tabular}{|c|c|c|}
\hline Date/Time & Comments & Initials \\
\hline $9150 / 13.35$ & Frocedure nofe: when deconinge & BBC \\
\hline & GEE fugars manually isolate & \\
\hline & at ATIE 40 entance safory & \\
\hline $9 / 30 \quad 1340$ & Pege Presure $=2.1^{T}{ }^{T} \mathrm{r}$. & \\
\hline & & \\
\hline & 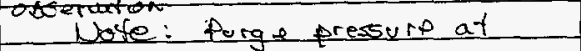 & \\
\hline & end of day last friday was & \\
\hline & $1,3^{\prime \prime}$ & \\
\hline & 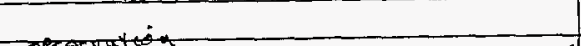 & \\
\hline & Nate: Flos optie cables reel & $\mathrm{ROC}$ \\
\hline & could be upplaced w/ones that & \\
\hline & have one end a luay attarled. & \\
\hline & & \\
\hline$q^{\prime} \rho_{0}$ & CeE still sightly contamenated so & \\
\hline & will $\mathrm{tag}$ it Rest of ara is & \\
\hline & dean. & \\
\hline $1(0)$ & $k \rightarrow m o r+l$ SEE. & \\
\hline
\end{tabular}

Items to be recorded in the test $\log$ will consist of, as a minimum, dates/times for procedure start and stop, documentation of test exceptions, and commentary on any issues observed during testing. Each test log entry shall be signed and dated by the person making the entry. 


$$
\text { HNF-SD-WM-0TR-213, REV } 0
$$

$$
\text { ref WHC-SD-WHM-OTP-213, Rev } 0
$$

APPENDIX D, ACCEPTANCE SHEET

LDUA OTP Acceptance Sheet

The LDUA T-106 OTP is complete and the following objective has been met;

The objective is to successfully set up/assenble the LOUA and its sub systems at T-106, operate the LDUA inside of T-106, perform tasks with each available end effector within that tank.

TD find (quad)

Date $10 / 2 / 96$.

TWRS LDUA Cognizant Engineer fhefeforef Date 10.11.16.

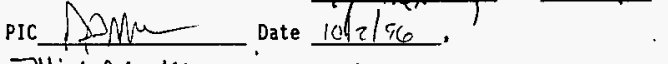

QEMichl一Mislez Date $10 / 2 / 96$.

Comments:

Page 16

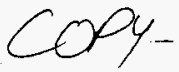

Page 41 


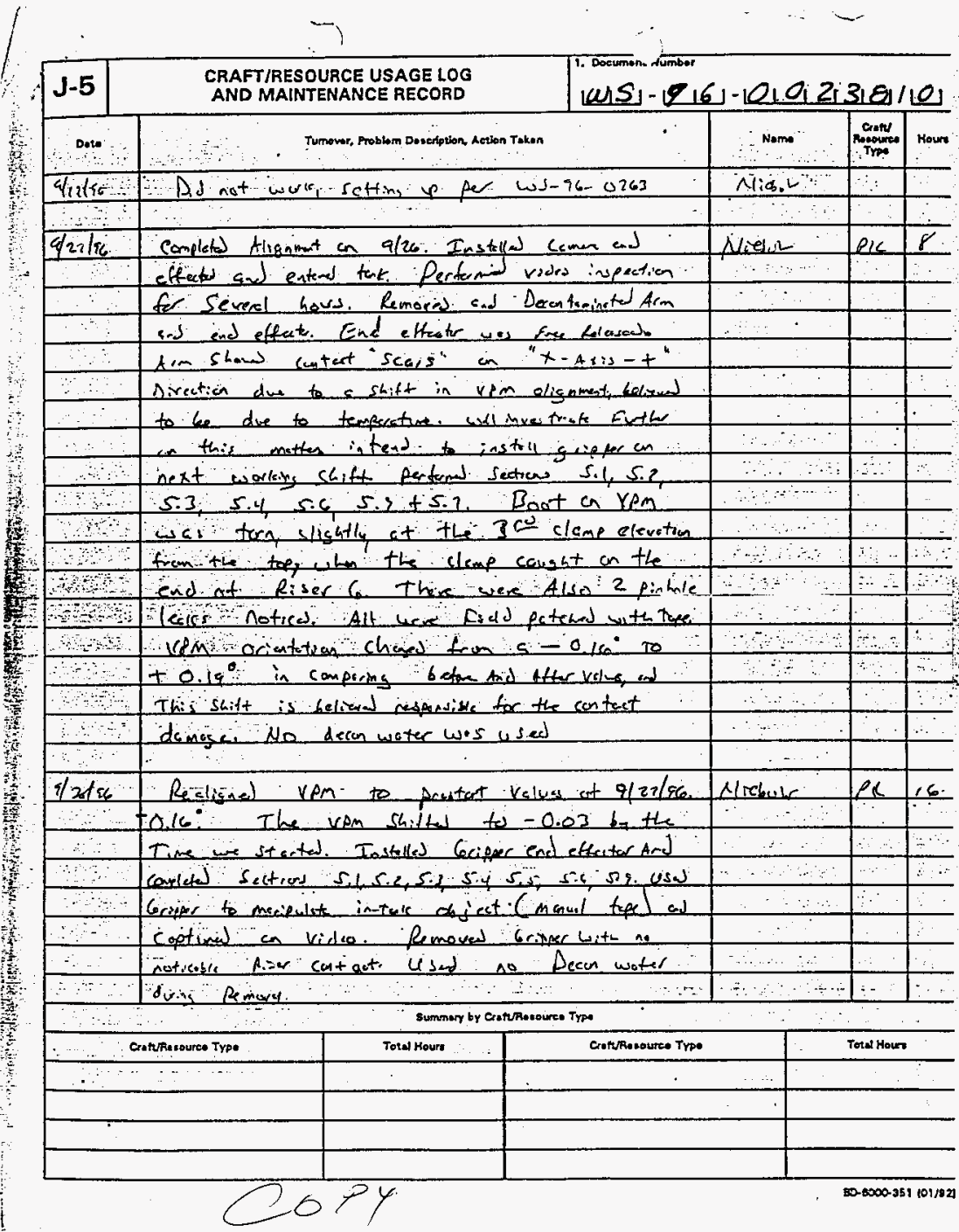




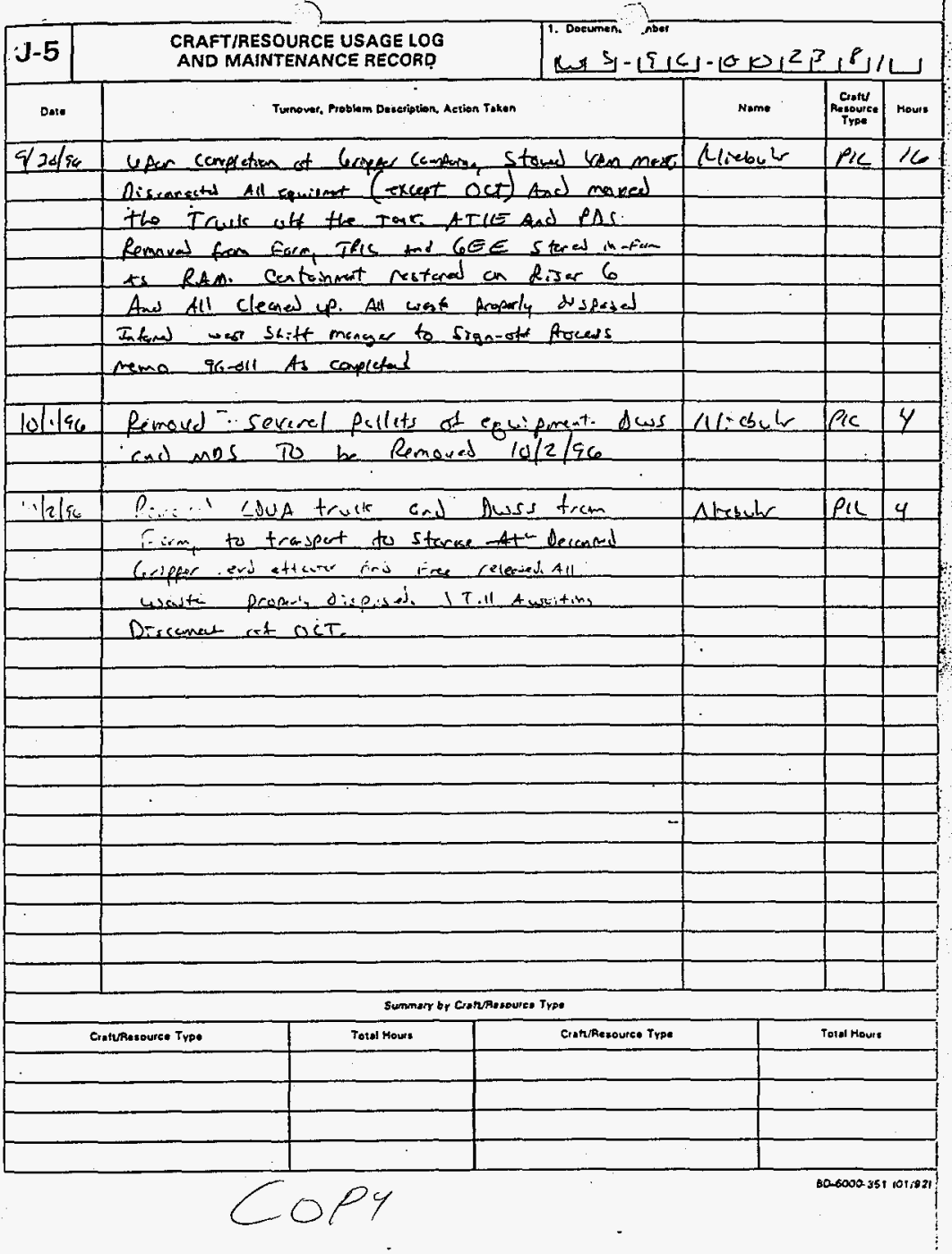




\begin{tabular}{|c|c|c|c|c|c|}
\hline \multicolumn{6}{|c|}{ DISTRIBUTION SHEET } \\
\hline \multirow{2}{*}{$\begin{array}{l}\text { To } \\
\text { Distribution }\end{array}$} & \multirow{2}{*}{\multicolumn{2}{|c|}{$\begin{array}{l}\text { From } \\
\text { Characterization }\end{array}$}} & & \multicolumn{2}{|c|}{ Page 1 of 1} \\
\hline & & & & \multicolumn{2}{|c|}{ Date $01 / 27 / 97$} \\
\hline \multicolumn{4}{|c|}{ Project Title/Work Order } & \multicolumn{2}{|c|}{ EDT No. 619111} \\
\hline \multicolumn{4}{|c|}{$\begin{array}{l}\text { Operability Test Report for LDUA in Tank T-106 } \\
\text { HNF-SD-WM-0TR-213, Rev. } 0\end{array}$} & \multicolumn{2}{|c|}{ ECN No. } \\
\hline Name & MSIN & $\begin{array}{l}\text { Text } \\
\text { With All } \\
\text { Attach. }\end{array}$ & Text Only & $\begin{array}{l}\text { Attach./ } \\
\text { Appendix } \\
\text { Only }\end{array}$ & $\begin{array}{l}\text { EDT/ECN } \\
\text { Only }\end{array}$ \\
\hline $\begin{array}{l}\text { ML McElroy } \\
\text { R Huckfeldt } \\
\text { G Kiebel } \\
\text { D Langlois } \\
\text { D Niebuhr } \\
\text { GA Barnes } \\
\text { Central Files }\end{array}$ & $\begin{array}{l}\text { S7-07 } \\
\text { R3-01 } \\
\text { K5-22 } \\
S 7-03 \\
S 7-03 \\
H 5-09 \\
A 3-88\end{array}$ & $\begin{array}{l}x \\
x \\
x \\
x \\
x \\
x \\
x\end{array}$ & & & \\
\hline
\end{tabular}

